\title{
Transversalidades entre Rudolf Otto e o Pentecostalismo
}

\author{
Transversalities between Rudolf Otto and the Pentecostalism
}

Claiton Ivan Pommerening*

\begin{abstract}
Resumo
O pentecostalismo, diferentemente das religiões mais letradas, conseguiu incorporar à sua vivência de fé diária as manifestações experienciais do numinoso. Para entender esses fenômenos de forma racional, escolheu-se traçar comparações da religiosidade pentecostal com a obra de Rudolf Otto, O sagrado, lançada em 1917 e que representou uma valiosa contribuição para compreender os fenômenos religiosos presentes principalmente nas religiões cuja ênfase recai sobre a experiência intensa com o sagrado, como é o caso do pentecostalismo. As hipóteses lançadas são que para o pentecostal pouco interessam as questões da sistematização racional, pois sua conversão e posterior vivência da fé são valorizadas a partir da experiência viva com o numinoso, através das manifestações do Espírito Santo. Dessa forma a valorização maior recai sobre a experimentação do numinoso através do êxtase, do transe e do misticismo.
\end{abstract}

\section{Palavras-chave}

Numinoso. Pentecostalismo. Experiência religiosa. Racionalidade.

\begin{abstract}
Pentecostalism, unlike the most literate religions, was able to incorporate into its daily faith experience the experiential manifestations of the numinous. In order to understand these phenomena in a rational way, it was chosen to draw comparisons of pentecostal religiosity with the work of Rudolf Otto, The sacred, which was published in 1917 and which represented a valuable contribution to understanding the religious phenomena present mainly in religions whose emphasis falls on experience with the sacred, as is the case with Pentecostalism. The hypotheses are that the questions of rational systematization are of little interest to the Pentecostal, since their conversion and later experience of faith are valued from living experience with the numinous through the manifestations of the Holy Spirit. In this way, the greater valuation relies on the numinous experimentation through ecstasy, trance and mysticism.
\end{abstract}

\section{Keywords}

Numinous. Pentecostalism. Religious experience. Rationality.

[Texto recebido em março de 2018 e aceito em junho de 2018, com base na avaliação cega por pares realizada por pareceristas ad hoc]

* Doutor em Teologia. Professora na Faculdade Refidim. E-mail: claiton@ceeduc.edu.br 


\section{Introdução}

A obra de Rudolf Otto (1869-1937), O sagrado, servirá de guia orientador deste artigo, especialmente por sua relação traçada entre o racional e o não racional na explicação e experimentação do divino, nesse texto analisado especificamente na relação com o pentecostalismo. Embora certamente Otto não teve contato direto com o pentecostalismo, no entanto, traçou de forma vívida vários dos fenômenos religiosos verificados no pentecostalismo. Por esse motivo, a obra de Otto serve com brilhante clareza para tentar entender a experiência religiosa verificada no pentecostalismo em seus vários desdobramentos e compreensões. O autor teve influência de Martinho Lutero, Immanuel Kant, Nathan Söderblom e, especialmente, o aporte aqui realizado é influenciado por Friedrich Schleiermacher.

A obra de Otto aproxima-se do pensamento religioso pentecostal por expor a experiência com o numinoso e como as pessoas sentem e reagem diante do sagrado. Ele foi um teólogo alemão envolvido com a não racionalidade da religião, obtendo seu título de doutorado com a tese As concepções de Espírito Santo em Lutero. Embora Otto atuasse como um cientista da religião é indicado no meio acadêmico como etnocentrista, por propor seu olhar a partir do cristianismo, e especialmente o luteranismo.

\section{A transversalidade entre mito, racionalidade e não racionalidade}

Para a análise ora proposta, utilizou-se o binômio racional/não racional, entretanto as culturas que as compõem são perpassadas, em maior ou menor medida, por uma e outra. Cada uma tem características próprias, como analisa Ênio Brito: “o pensamento oral [menos racional] pode ser sofisticado e de certa maneira reflexivo, mas não é capaz de criar cadeias elaboradas de causas em sequência linear como o pensamento analítico apoiado em textos". ${ }^{1}$

Pelo fato do pentecostalismo ter surgido entre classes pobres e oprimidas, e como uma reação à marginalidade social e à institucionalização protestante ${ }^{2}$ e católica, a teologia no pentecostalismo necessita de formas menos elaboradas e racionalizadas de religiosidade, com ênfase na oralidade, abrindo mão até da necessidade do estudo acadêmico da teologia em alguns casos, pois muitos fiéis não têm acesso à educação formal, aderindo assim ao caminho menos exigente da experiência.

Segundo Hollenweger, o movimento pentecostal é revolucionário porque oferece alternativas à teologia escrita e permite que o pensamento cristalizado na forma escrita se

1 Para uma análise do pentecostalismo na questão oralidade e letramento consultar: POMMERENING, Claiton Ivan. Oralidade e escrita na Teologia Pentecostal. Azusa Revista de Estudos Pentecostais, Joinville, v. I, n. 1, p. 23-62, jul. 2010.

2 MENDONÇA, Antônio Gouvêa; VELASQUES FILHO, Prócoro. Introdução ao protestantismo no Brasil. São Paulo: Loyola, 1990. p. 240. 
torne fluido através da oralidade, oferecendo possibilidades para pessoas que somente podem falar, que não conseguem se expressar de forma escrita. $\mathrm{O}$ acesso à palavra permite a democratização do saber, pois suprime a abstração sistemática e racional dos conceitos. ${ }^{3}$ $\mathrm{O}$ autor salienta ainda que a teologia oral, e portanto mais experiencial, tem igualdade de direitos sobre a escrita. Argumenta que Deus não criou faculdades mentais inferiores umas às outras, se compararmos a razão com a emoção, a devoção contemplativa com a dança, etc. ${ }^{4}$

A coisa de que se fala torna-se comum aos interlocutores na oralidade, já na escrita ocorre o distanciamento entre ambos. ${ }^{5}$ Quando uma lenda ou história é escrita, cristalizase a história na escrita. A oralidade não se cristaliza, logo, se adapta e se contextualiza facilmente ao meio, não se encerra como na forma escrita, permitindo múltiplas aplicações e nuances.

Leenhardt escreveu que toda mentalidade humana é composta de dois elementos primordiais: mito e razão. ${ }^{6}$ Quanto a estes dois elementos, escreveu: "não existe anterioridade em relação ao outro", pois na história do pensamento humano a razão é tão antiga quanto o mito, não existindo nenhum idioma que seja desprovido de racionalidade. O erro está em comparar "civilizados" e "não civilizados", em lugar de "julgar cada qual segundo a medida que lhe é peculiar". 7 Salienta ainda que "toda mentalidade comporta um aspecto racional e um aspecto mítico. Mas um desses aspectos pode suplantar o outro ao ponto de recobri-lo quase inteiramente". ${ }^{8}$

Não há na realidade passagem de um pensamento mítico a um pensamento racional, como também não há, conforme Leenhardt,

Sucessão entre um período mítico anterior e uma nova era racional posterior, e nem mesmo existia a transformação de um estado de personagem a um estado de pessoa. Todos estes aspectos e estados se encontram enovelados, fundidos, misturados, indiferentes e virtuais. ${ }^{9}$

3 HOLLENWEGER, Walter J. El Pentecostalismo: Historia y doctrinas. Buenos Aires: La Aurora, 1976. p. 23.

4 HOLLENWEGER, 1976, p. 26-27.

5 RICOEUR, Paul. Interpretação e ideologias. 2.ed. Rio de Janeiro: F. Alves, 1988. p. 54.

6 "O termo mito é, com efeito, uma velha palavra [...] com o sentido enfraquecido de fábula ou narrativa relacionada com os deuses. [...] $\mathrm{O}$ acontecimento que o mito circunscreveu originalmente é levado ao coração dos ouvintes pelo efeito da recitação. A narrativa age como uma liturgia, que atualiza na alma dos fieis o acontecimento religioso inicial". LEENHARDT, Maurice. O mito. Religião e sociedade, Rio de Janeiro, v. 14, n. 1, p. 90, mar. 1987. Seguindo o conceito de Eliade, os mitos "revelam que o mundo, o homem e a vida têm uma origem e uma história sobrenatural, e que essa história é significativa, preciosa e exemplar". ELIADE, Mircea. Aspectos do mito. Lisboa: Edições 70, 1963. p. 24.

7 LEENHARDT apud QUEIROZ, Maria Isaura Pereira de. Rumos do pensamento etnológico na França: a atualidade de Maurice Leenhardt. Religião e Sociedade, Rio de Janeiro, v. 14, n. 1, p. 72, mar. 1987.

8 LEENHARDT apud QUEIROZ, 1987, p. 83.

9 LEENHARDT apud QUEIROZ, 1987, p. 81. 
Ao invés de "encarar a tensão entre fé e razão, e entre crença e razão, segundo uma postura defensiva, é preciso que sejamos capazes de perceber a interação entre fé, crença e razão em termos construtivos".${ }^{10}$ Cada vez mais a religiosidade contemporânea busca aquilo que não encontra em outros lugares: a magia e o mito. ${ }^{11}$ Entende-se que estas categorias são irracionais, porém, elas mesmas, exigem certo sentido lógico da ação e perpassam todas as religiões, mesmo aquelas consideradas racionais e letradas.

Fé e razão não são atividades opostas ou separáveis do sujeito humano. [...] a fé é uma forma de raciocínio. [...] A ação do espírito humano, que é liberdade reflexiva em seu dinamismo em prol de um objeto de compromisso último e de lealdade, desenvolve-se na e por meio da mente humana. De certa maneira, toda consciência humana envolve uma razão questionadora e crítica; no nível profundo de sua reflexividade, sempre remete a si mesma. ${ }^{12}$

A construção da religiosidade e da fé, adquiridas nas igrejas, especialmente as pentecostais, entram em conflito, em sua grande maioria, com os postulados racionais. Eles são motivados por sua vida religiosa ou pela experiência de conversão, ${ }^{13}$ geralmente de ruptura,14 e sua formação religiosa ainda não foi devidamente racionalizada. Além disso, a experiência extraordinária com o numinoso tende a colocar a racionalização num lugar secundário. ${ }^{15}$

A linguagem do [recém-convertido] é confessional, emotiva. Ele canta a sua nova experiência. A linguagem da comunidade, entretanto, contém uma elaboração teórica dessa experiência. O converso revela a sua alma. A comunidade articula os sentimentos com uma cosmovisão compreensiva. $\mathrm{O}$ converso ainda está sob o encanto mágico de um novo objeto que o fascina e que transformou suas emoções. A comunidade já submeteu esse objeto a um processo de reflexão globalizante. O converso se encontra diante de algo misterioso e maravilhoso. A comunidade já transformou o misterioso e

10 HAIGHT, 2004, p. 59.

11 BOMFIM, Adailson Jose Rosendo. Um “alarido" neopentecostal: diversidade e ressignificação simbólica na Igreja Universal do Reino de Deus. Scientia Plena, São Cristovão, v. 3, n. 5, p. 66, 2007.

12 HAIGHT, 2004, p. 59.

13 SUNG, Jung Mo; MIGUEZ, Nestor; WIRTH, Lauri. Missão e educação teológica. São Paulo: Aste, 2011. p. 171.

14 Este conceito para as gerações subsequentes começa a não ser mais aplicável, pois a necessidade ontológica vai desaparecendo com o tempo. "Os filhos nascidos em famílias protestantes encaram a conversão mais como prática cultural da família, [...] ela acontece, não raramente, desprovida de crise emocional". RIVERA, Paulo Barrera. Tradição, transmissão e emoção religiosa: sociologia do protestantismo na América Latina. São Paulo: Olho d'Água, 2001. p. 168. Alessandro Bartz indica ainda que o conceito weberiano de conversão não atende mais às idas e vindas do atual transito religioso. BARTZ, Alessandro. Percursos religiosos e adesão: comunidades urbanas da IECLB como estudo de caso. 2013. Tese (Doutorado) - Programa de Pós-Graduação em Teologia, Escola Superior de Teologia, São Leopoldo, 2013. p. 319.

15 RIVERA, 2001, p. 229. 
maravilhoso em conhecimento. Por isso, a própria comunidade se refere ao convertido como aquele que "ainda não sabe no que crê". ${ }^{16}$

Por outro lado, a descrição do mito, conforme Croatto, não tem sintonia com o saber da ciência, não se misturam, pois são de ordens distintas. Isso extingue o mito e pode ainda esvaziá-lo através da explicação racional. ${ }^{17} \mathrm{D}^{\prime}$ Epinay afirma que entre os pentecostais a fé, o Espírito e o sentimento são mais importantes que a letra e a inteligência e os que são contrários aos estudos alegam que este mata a fé e o sentimento. ${ }^{18}$

Daniel Lobos afirma que a conversão intelectual, geralmente fere a identidade comunitária e traz crises de fé. Ao se convencer de que o aprendizado racional, geralmente na academia, suplanta o de sua comunidade, questionará seu sistema de crenças anterior, passará a entrar em conflito com este podendo abandonar a igreja a qual pertencia ou ser rechaçado pela liderança. ${ }^{19}$ Entretanto, deve-se entender que a crise de fé é necessária para que o sujeito amadureça sua fé, muitas vezes mitológica e romantizada. Nesse sentido, a teologia desempenha importante papel. Contudo, isto não poderá ser feito destruindo esta fé, mas ressignificando-a respeitosamente. Sung, Miguez e Wirth apontam uma possível solução a este problema afirmando que pode-se compreender e expressar de modo diferente a mesma experiência na medida em que se percebe "que a linguagem/cultura que [se utiliza] não é adequada para dar conta da experiência". ${ }^{20}$

Conforme Durkheim, ${ }^{21}$ a eficácia religiosa se dá na emotividade e não na intelectualidade. Ela é eficaz pela força para viver e agir transmitidos ao fiel e não pelos conhecimentos intelectuais que tem. A ênfase prioritariamente racional pode incorrer em grave desrespeito à fé expressa nas comunidades, pelo fato de que a entrega absorta em Deus e a confiança incondicional em sua providência está em contraste com o "saber" e, geralmente, a experiência com o sagrado exige a mortificação do orgulho intelectual. ${ }^{22}$

16 ALVES, Rubem. Religião e repressão. São Paulo: Teológica/Loyola, 2005. p. 84-85.

17 CROATTO, José Severino. As linguagens da experiência religiosa: uma introdução à fenomenologia da religião. São Paulo: Paulinas, 2001. p. 309.

18 D'EPINAY, Christian Lalive. El refugio de las masas: estudio sociológico del protestantismo chileno. Concepción (Chile): USACH/IDEA/CEEP, 2010. p. 296.

19 LOBOS, Daniel. Problemas y desafíos que presenta el educando pentecostal al plan de estudios teológico de nivel universitario. In: CHIQUETE, Daniel; ORELLANA, Luis. (Eds.). Voces del pentecostalismo Latinoamericano: identidade, teologia e historia. v. 8. Concepción (Chile): RELEP/CETELA/ASETT, 2003. p. 106.

20 SUNG; MIGUEZ; WIRTH, 2011, p. 172-173.

21 "A verdadeira função da religião não é nos fazer pensar [...], mas nos fazer agir, nos ajudar a viver. O fiel que comungou com o seu deus não é apenas homem que vê verdades novas que o incrédulo ignora: é homem que pode mais. Ele sente em si força maior para suportar as dificuldades da existência e para vencê-las. Está como que elevado acima das misérias humanas, porque está elevado acima de sua condição de homem e crê-se salvo do mal". DURKHEIM, Émile. As formas elementares da vida religiosa: o sistema totêmico na Austrália. São Paulo: Martins Fontes, 2000. p. 424-425.

22 WEBER, Max. Economia e sociedade: fundamentos da sociologia compreensiva. Brasília: UNB; São Paulo: IOESP, 1999. p. 380. 
Conforme já afirmara Weber, a religiosidade popular sacrifica o intelecto, sem achar isto inconveniente, para permanecer entregue ao conforto da fé.

Toda devoção fiel genuinamente religiosa, de natureza qualquer, inclui direta ou indiretamente, em algum ponto, o "sacrifício do intelecto", em favor daquela qualidade espiritual específica, supra-intelectual, da entrega absoluta e da confissão, cheia de confiança: credo, non quod, sed quia absurdum est. ${ }^{23}$ Aqui, com alhures, a religiosidade de salvação das religiões crentes num deus supramundano sublinha a insuficiência da força intelectual em face da sublimidade de Deus. ${ }^{24}$

A função fundamental da religiosidade não é sua formulação intelectual, pois a "teoria não é a parte mais significativa ou essencial da religião", é a adoração e o culto a parte fundamental dela. ${ }^{25}$ "A religião não se esgota em enunciados racionais. Estes são predicados essenciais de um elemento suprarracional, onde se situa o objeto essencial da religião (o numinoso). [...] Eliminar o numinoso significa reduzir a religião a um fim puramente racional e moral", 26 que não pode ser definido, apenas interpretado. Otto salienta nesse sentido que a formulação das doutrinas e da ortodoxia não valorizou o elemento irracional, para mantê-lo vivo na experiência religiosa, deveria tê-lo em paralelo com a experiência religiosa. ${ }^{27}$

Queiroz lembra que a predominância hierárquica entre uma forma e outra de acessar o sagrado, poderão remeter a novas formas de primitivismo podendo haver uma "dominação absoluta de uma ou outra destas duas maneiras de ser". Mas ele destaca que "a predominância da racionalidade promoveu um retorno, não a um arcaísmo autêntico, e sim a uma ordem ainda pior, a uma nova forma de barbárie", ${ }^{28}$ onde a racionalidade define o que é certo ou errado na religião.

Para se conhecer a importância da experiência e da emotividade entre os pentecostais, faz-se necessário entender os "princípios inconscientes coletivos segundo os quais este grupo constrói sua realidade", portanto, é preciso "partir de suas emoções fundadoras". ${ }^{29}$ Para tal tentou-se uma aproximação do pentecostalismo com o pensamento de Rudolf Otto, que será examinado a seguir.

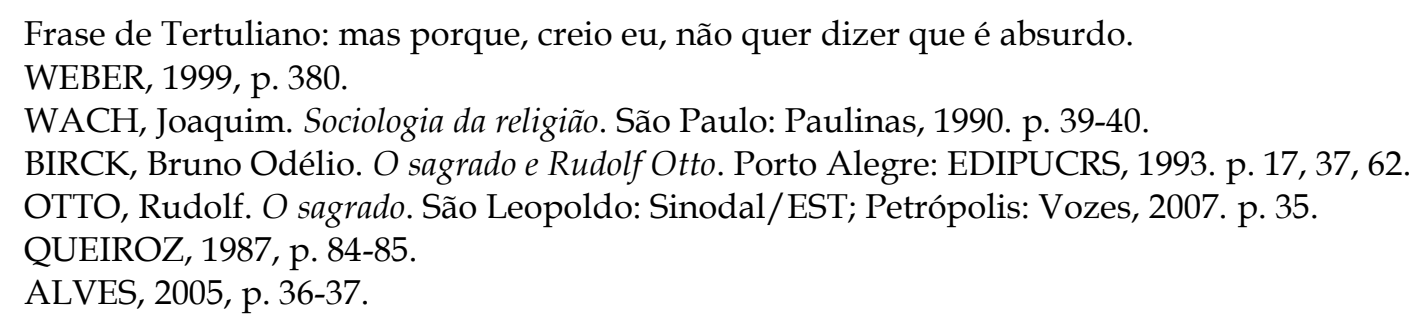




\section{O sagrado em Rudolf Otto}

O sagrado é o totalmente outro, aquele que é inatingível e inalcançável pelas categorias humanas, é aquele que somente é acessível porque se teofaniza, o que causa ainda mais assombro. Para os pentecostais, ele poderá ser alcançado se buscado com intensidade através da oração, da consagração, do jejum e da observância de determinadas regras religiosas. Portanto, no pentecostalismo a teofania, embora entendida como uma graça divina, adquire certa participação meritória.

Otto salienta que existe uma diferença entre o que é produzido por nossa faculdade do conhecimento daquilo que é recebido "por meio das nossas impressões, excitada pela experiência sensível" ${ }^{30}$ Ele propõe assim uma diferenciação entre o racional e o não racional, este último não significando irracionalidade da psique, apenas indica que existem apreensões na psique humana que transcendem o binômio racionalidade/irracionalidade, sendo o numinoso o núcleo, o elemento principal na experiência religiosa. Assim, Otto quer revelar o elemento não racional da religião que foi obscurecida pelo racionalismo. ${ }^{31}$

\section{O sentimento de criatura}

Otto convida o leitor a lembrar-se de momentos de forte excitação religiosa. Ele as chama de "estados psíquicos de solene devoção e arrebatamento",32 de "sentimento de criatura que afunda e desvanece em sua nulidade perante o que está acima de toda criatura" ${ }^{33}$ Não se trata apenas da nulidade perante o absolutamente avassalador, no conceito de Schleiermacher, mas que também Ele é inefável.

O sentimento de criatura é também um efeito colateral do sentimento de receio que leva a uma dependência absoluta do numinoso e "pressupõe uma sensação de 'superioridade (e inacessibilidade) absoluta'". ${ }^{34}$ Tal sentimento é aquilatado no pentecostalismo pelas classes sociais que não tem acesso aos bens de consumo e aos cuidados médicos e à segurança, fazendo-os dependerem ainda mais dos benefícios oriundos do arrebatamento psíquico e conforto simbólico que lhe é provido na experiência religiosa.

\section{Mysterium tremendum}

Este aspecto não é racional e não pode ser conceituado, somente pode ser indicado sentimentalmente pela psique e pode levar à "profunda devoção meditativa". Ou ainda pode "eclodir do fundo da alma em surtos e convulsões" e "induzir estranhas excitações,

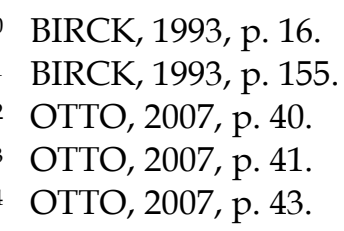


inebriamento, delírio, êxtase". ${ }^{35}$ É possível levar ao horror e estremecimento como alguém diante de uma assombração. Pode se manifestar como bárbaro e selvagem, mas também como refinado e culto. ${ }^{36} \mathrm{O}$ próprio Otto admite que não há o que dizer diante da experiência. No pentecostalismo ela se aproxima do inebriamento vocálico produzido pelo batismo no Espírito Santo, que se transforma em êxtase e muitas vezes até mesmo em transe. ${ }^{37}$

\section{O Tremendum (arrepiante)}

É uma reação emocional que se aproxima do temor e do receio da ira de Deus. Citando Jó $(9.34$; 13.21) Otto diz que é algo "fantasmagórico". Porém esta é uma designação inferior para o numem, pois evoca receio demoníaco, mas não é o receio diante de coisas "naturais". Pode ser designado como pasmo, estupefação, assombro místico, arrepio, pânico apavorado ou sinistro. ${ }^{38} \mathrm{O}$ temor diante do demoníaco seria uma forma primitiva de se chegar ao numinoso, que pela carência de refinamento racional, cria um "pré-deus", que depois evolui até se tornar um deus Tremendum. 39

\section{O avassalador (majestas)}

No latim majestade tem o aspecto de "inacessibilidade absoluta", poder, domínio, hegemonia, ou supremacia absoluta, segundo Schleiermacher. Seria o oposto dos sentimentos experimentados pela criatura, de sensação de dependência, de ser condicionado, de aniquilação de si mesmo, de ser pó e cinza diante da majestade. Uma das características do pentecostalismo é que esse produz nos seus adeptos uma consciência elevada de pecado e mecanismos de busca intensa de uma vida devota e separada do mundo, utilizando um jargão próprio, que significa uma contracultura àquilo que a sociedade vive, acusando-a de pecadora; portanto, estar diante da divindade e compactuar das práticas profanas é atentar contra sua majestade.

\section{O enérgico}

Seria a energia do numinoso, sentido na ira e expresso "simbolicamente na vivacidade, paixão, natureza emotiva, vontade, força, comoção, excitação, atividade,

35 Peter Berger afirma que situações de êxtase são situações normais, "sociedades ou grupos sociais inteiros podem, em tempo de crise, passar coletivamente por tal situação". BERGER, Peter L. O dossel sagrado: elementos para uma teoria sociológica da religião. São Paulo: Paulinas, 1985. p. 57.

36 OTTO, 2007, p. 44-45.

37 A diferença entre êxtase e transe é que o primeiro são estados alterados de consciência mas o indivíduo permanece no controle de suas faculdades mentais, o segundo extingue qualquer controle ou consciência de si.

38 OTTO, 2007, p. 45-51.

39 SOUZA, Alexandro Ferreira de. A narrativa de um malogro: vivência e linguagem religiosas em A paixão segundo G.H., de Clarice Lispector, examinadas a partir de Rudolf Otto. 2009. Dissertação (Mestrado em Teologia) - Programa de Pós-Graduação em Ciência da Religião, Universidade Federal de Juiz de Fora, Juiz de Fora, 2009. p. 27-28. 
gana" ${ }^{40}$ Atua no ser humano como a força que condiciona e desperta ao zelo que progride para a prática ascética, luta contra o mundo e a carne, na formulação da piedade e na força para realizar atos heroicos. Pode também ser o ardor com que o místico se aproxima, com amor impetuoso, do numem. ${ }^{41}$

O ardor missionário e a paixão com que o pentecostal se envolve com as atividades eclesiais e evangelísticas é oriundo dessa característica de experiência com o divino, que o leva a sacrifícios extremos, inclusive financeiros, como meio de compartilhar dessa natureza divina.

\section{O mysterium}

Otto conceitua mysterium como sendo o espantoso, o psicologicamente atingido por um milagre ou prodígio que leva o indivíduo a ficar boquiaberto e embasbacado diante da estranheza absoluta. Para diferenciar de tremendum Otto cita Mc 10.32: "e estavam pasmos [mysterium, estupor], e os que acompanhavam tinham medo [tremendum]". Já o "totalmente outro" (ganz andere) é o incompreensível e inconcebível, aquilo que foge ao "entendimento na medida em que transcende categorias", 42 podendo contrapor-se a elas, chegando a ser paradoxal. Pode confundir, ofuscar, contrapor-se e contradizer-se. É o que "ultrapassa a experiência natural do homem" e se manifesta "como uma realidade inteiramente diferente das realidades 'naturais" ${ }^{43}$

O milagre é uma categoria presente na vida do pentecostal, ele constantemente está assombrado com pequenas coisas na vida que atribui à intervenção e cuidados divinos, que leva a um sentimento de pertença e bem estar, portanto, coisas corriqueiras e cotidianas podem ser atribuídas ao mysterium, embora possam acontecer também milagres no sentido real da palavra que contrapõe a ordem natural da natureza.

\section{O fascinante}

O numinoso, em contrataste com o elemento distanciador do tremendum, é algo atraente, cativante, arrebatador, encantador e fascinante, podendo levar ao delírio e ao inebriamento. Otto designa este caráter contrastante como o "mais estranho e notável fenômeno na história da religião". O que o "demoníaco-divino tem de assombroso e terrível para a nossa psique, ele tem de sedutor e encantador" ${ }^{44}$ A criatura estremece de receio do tremendum e ao mesmo tempo sente-se atraída pelo fascinans. O elemento

40 OTTO, 2007, p. 55.

41 SOUZA, 2009, p. 30.

42 OTTO, 2007, p. 62.

43 ELIADE, Mircea. O sagrado e o profano: a essência das religiões. 2.ed. São Paulo: Martins Fontes, 2008. p. 16.

44 OTTO, 2007, p. 68. 
racional deste aspecto do numinoso são amor, misericórdia, compaixão e consolo, como aspectos naturais da experiência psíquico-religiosa.

É o fascinante que dá início a processos como "estar no espírito" e de mística enobrecida, as quais levam a exclamações de exaltação. $O$ algo mais do elemento fascinante são as exageradas exaltações dos bens de salvação. Além desta categoria se encontram as experiências de conversão e renascimento. Muitas vezes, é difícil exprimilas, podendo desembocar em "excitado enlevo, deixando a pessoa fora de si, numa exaltação que muitas vezes tange o bizarro e o anormal". ${ }^{45}$

O sentimento de solenidade que o culto adquire, quando celebrado com profundidade e seriedade, é o elemento fascinante, que preenche e satisfaz a alma de modo inefável. O fascinante é o que provoca estados de profunda adoração e leva o crente à chorar e derramar suas emoções em completude diante da revelação de amor, bondade e misericórdia do divino.

\section{O assombroso}

Caracterizado como algo "imenso, tão grande que ultrapassa nossa capacidade de imaginação espacial". Pode ser também o "totalmente inesperado, tão diferente a tal ponto de causar estranheza". ${ }^{46}$

\section{O augustum}

Expressão como a que se encontra em Isaías "meus lábios são impuros, venho de um povo de impuros lábios", surpreende tanto "quanto à resposta-sentimento autodepreciativa" e de "espontaneidade imediata, quase que instintiva", sendo dada num "reflexo psicológico imediato e involuntário" diante da resposta de sentir o numinoso, desvalorizando-se diante dele, não como transgressão moral necessariamente, mas como distanciamento humano (como profanidade) ante a augusta presença. "Trata-se do valor numinoso, o protofundamento e origem não racional primeira de todos os possíveis valores objetivos". 47 É a exigência do numinoso em compromisso moral, algo que exige "respeito incomparável", precisando ser reconhecido como mais válido, elevado, "situado acima de todos os valores racionais", que reconhece e exalta algo "inconcebivelmente valioso", e que tem o "direito de reivindicar culto" ser exaltado porque é "digno de exaltação". ${ }^{48}$

Como esse augustum é elemento essencial no numinoso, a religião, independentemente de toda e qualquer esquematização moral, é essencialmente obrigação íntima, normatividade e vínculo para a consciência, é obediência e culto, não pela pura e

45 OTTO, 2007, p. 75.

46 OTTO, 2007, p. 80.

47 OTTO, 2007, p. 90-91.

48 OTTO, 2007, p. 91-92. 
simples coerção pelo avassalador, mas pelo curvar-se em reconhecimento diante do mais sagrado valor. 49

\section{O racional e o não racional no pentecostalismo: aproximações com Rudolf Otto}

Certamente o pentecostalismo não sobreviveria se lhe tirasse o caráter não racional, dada a grande atração que este proporciona aos que migram para ele. De maneira imbricada tem-se o fato de que caminham lado a lado intuições interiores do "coração", paradoxalmente racionalizadas, que governam a tomada de decisões de muitos fiéis, e a leitura bíblica literalista, embora não seja uma hermenêutica única.

O Espírito Santo é o símbolo religioso por excelência do Pentecostalismo. A construção deste símbolo ${ }^{50}$ se dá a partir da conversão e se aperfeiçoa com o batismo no Espírito Santo como uma "presença que sai das sombras, e certa testemunha que a reconhece". Compõe-se numa "relação presencial que sela, de forma clara, tal encontro". Como resultado desse encontro surge uma revelação em forma de "palavra sagrada",51 a glossolalia, que assume a função de sinal. ${ }^{52}$ Nesse sentido, Rubem Alves salienta que a religião é o encontro com o fim último do ser humano. "A religião é a memória de uma unidade perdida e a nostalgia por um futuro de reconciliação". ${ }^{3}$

Através da experiência do batismo no Espírito Santo e das experiências posteriores de glossolalia, o numinoso fascinante (conforme classificação de Otto) revela-se ao crente, fazendo-o comprovar na experiência, que o amor de Deus não é apenas um conceito teológico racional, mas que este amor também é acessível sentimentalmente provendo bem estar à alma e promovendo curas de traumas e tragédias da vida, trazendo possibilidade de suportar as injustiças sociais e sofrimentos oriundos da situação social e ou emocional da qual se origina o crente.

Segundo Rudolf Otto, o racional é tudo que pode ser explicável ou mensurável numa religião e que facilmente se explica em conceitos humanos compreensíveis; já o não racional relaciona-se com o que há de mais profundo na religião, o que toca a realidade última do ser humano, o não explicável, o inefável, o numinoso. Isto não significa que o não racional não possa se tornar racional a partir da explicação da religiosidade e da sistematização de suas crenças em dogmas teológicos. Desta forma, percebe-se que quanto mais informal for uma religiosidade, mais não racional ela é. Contudo, na medida em que seus teólogos a sistematizam perde-se esta característica. Com isso, inúmeros conceitos

49 OTTO, 2007, p. 92.

50 “O símbolo é, na ordem da expressão, a linguagem originária e fundante da experiência religiosa, a primeira e a que alimenta todas as demais". CROATTO, 2001, p. 81.

51 TRÍAS, Eugenio. Pensar a religião: o símbolo e o sagrado. In: DERRIDA, Jacques; VATTIMO, Gianni (Orgs.). A religião. São Paulo: Estação Liberdade, 2000. p. 120.

52 CROATTO, 2001, p. 85.

53 ALVES apud REBLIN, Iuri A. Outros cheiros, outros sabores... o pensamento teológico de Rubem Alves. São Leopoldo: Oikos, 2009. p. 135. 
religiosos se tornam frios quando apenas superficialmente conseguem explicar determinados fenômenos e características da divindade. A teologia pode dessacralizar os símbolos de fé mais primitivos do indivíduo, ou seja, segundo Croatto, "quando o sentido do símbolo é preso e traduzido em uma linguagem racional, assiste-se a seu esvaecimento". 54

A linguagem da experiência religiosa é profundamente simbólica, por outro lado a reflexão reduz ou pode até mesmo extinguir o símbolo. Croatto apresenta quatro formas de extinção do símbolo: pelo conceitualismo e positivismo que tentam explicar tudo pela experiência comum, do concreto e do verificável; pela dogmática que o reduz a uma linguagem racional; pelas hermenêuticas redutoras do símbolo que iguala o simbolizante ao símbolo; e pela leitura historicista da Bíblia com suas interpretações literais que excluem a possibilidade da inconcretude e destruição dos mitos. ${ }^{55}$

Neste sentido, Otto critica as dogmáticas afirmando que:

Nas dogmáticas essas coisas que necessariamente têm cunho não teórico, não conceitual e ligado ao sentimento, devido à sua natureza irracional por excelência, fugindo à análise conceitual rigorosa, são desenvolvidas em teorias conceituais e transformadas em objeto de especulação, resultando finalmente [num] cálculo quase que matemático [...]. ${ }^{56}$

No pentecostalismo pode-se afirmar que o racional manifesta-se também na maneira como as doutrinas e os costumes assumem importância na vivência diária do crente e formatam suas decisões e modo de vida. ${ }^{57}$ Seria a Palavra explicada e sistematizada. Imbricado com isto está a irreverência e a imprevisibilidade das manifestações do Espírito que, neste sentido, assumem caráter numinoso e não racional. Numinoso porque leva à fascinação, ao terror, ao aniquilamento, à reverência e ao assombro diante do mistério que se revela, e é não racional porque apela aos anseios mais profundos da alma humana, não mensuráveis e inexplicáveis. Por isso, certamente o pentecostalismo tem sido motivo de atração para milhares que se abrigam em seu colo confortável e selvagem (eros religioso), ao mesmo tempo. ${ }^{58}$

A experiência de êxtase vivenciada no pentecostalismo é uma profunda realidade na obra de Otto, que é a vivência sentimental do divino, o sentir, ${ }^{59}$ quase que uma

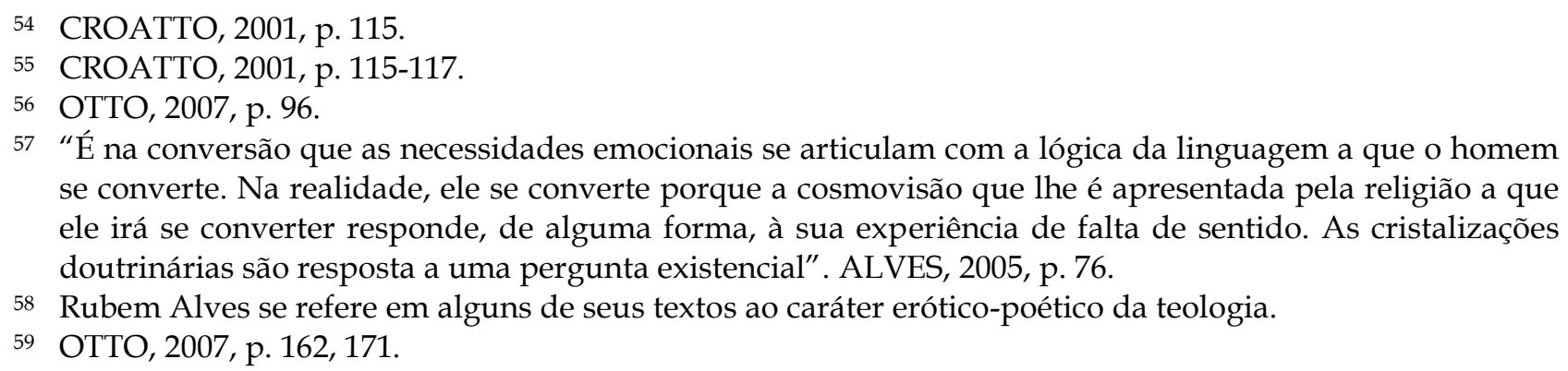
se converte. Na realidade, ele se converte porque a cosmovisão que lhe é apresentada pela religião a que ele irá se converter responde, de alguma forma, à sua experiência de falta de sentido. As cristalizações doutrinárias são resposta a uma pergunta existencial". ALVES, 2005, p. 76.

58 Rubem Alves se refere em alguns de seus textos ao caráter erótico-poético da teologia.

59 OTTO, 2007, p. 162, 171. 
experiência bruta do numinoso. ${ }^{60}$ Os aspectos brutos chegam algumas vezes a ser tão intoleráveis que os de fora rejeitam os cultos pentecostais e até mesmo se negam a visitar algum templo pentecostal por se acharem constrangidos em seu meio, alguns afirmando atividades demoníacas e ocultas. ${ }^{61}$ É o que Otto chamaria de "receio demoníaco". ${ }^{62}$ Mas não somente externamente observa-se isto, internamente também, quando se satiriza e ironiza, em comunidades mais elitizadas, as manifestações do Espírito.

O crente pentecostal constata o numinoso em sua vivência religiosa e, em consequência, desencadeia uma gama de experiências religiosas, levando-o a admirar a plenitude de seu objeto sagrado, a sentimentos de elevação superior que mais tarde servirão de base para a racionalização da fé. ${ }^{63}$ Porém, pode vir a perder o não racional inicial, ou perder "o primeiro amor" no dizer dos pregadores pentecostais, que sempre de novo convidam os fiéis a experimentarem a elevação quando já não a "sentem" mais.

O culto pentecostal é caracterizado por sua espontaneidade, barulho, desordem e, sobretudo, emotividade. O irracional de Otto. Contudo, aquilo que para um assistente desavisado perece desordem, na verdade, segue certo ritual predeterminado pelo "Espírito", naquilo que Bastide afirma ser a "imposição do meio social, sempre o mesmo, através das variações individuais" e "um fato social". 64

Segundo Alves, “o símbolo Cristo não é um símbolo secundário que deve apontar para o símbolo primário a filosofia de Cristo, mas o símbolo originário que aponta diretamente para um centro mágico de poder". ${ }^{65}$ Ficar retido na experiência de conversão posterga o aprendizado racional da fé, sob certo medo de perder o encanto desta experiência inicial. Embora esta experiência também tenha elementos de angústia sinistra que quer ser esquecida. ${ }^{66}$

A racionalidade religiosa implica o esquecimento de um aspecto sinistro da experiência emocional fundadora, [onde] combinam-se a fé e a dúvida. A dúvida é o terror que necessita ser esquecido. E isto se consegue na medida em que se instaura uma racionalidade que se apresente com as pretensões de conhecimento absoluto. Quando isto ocorre, a fé se transforma em dogma. ${ }^{67}$

60 OTTO, 2007, p. 169-172.

61 Estas conclusões externas surgiram porque em tempos passados alguns cultos, como Santa Ceia e Culto de Doutrina, eram feitos a portas fechadas e a entrada era permitida somente com carteira de membro. Dizia-se que havia cerimônias de ocultismo.

62 OTTO, 2007, p. 169.

63 SOUZA, 2009, p. 22-23.

64 BASTIDE, Roger. Estudos afro-brasileiros. São Paulo: Perspectiva, 1972. p. 310, 318.

65 ALVES, 2005, p. 86.

66 "[A racionalidade religiosa] se constrói a partir de uma experiência emocional fundadora, mas uma de suas funções é exatamente obscurecer o terror que tal experiência contém". ALVES, 2005, p. 113.

67 ALVES, 2005, p. 105. 
Assim, o aprendizado teológico, por ser racional, se enquadra nesta categoria, conforme Alves:

Todas as evidências que se oferecem ao converso, seja de ordem lógica ou científica, e que, de alguma forma, questionarem a sua experiência fundamental, será imediatamente rejeitada. Aqui só funcionam as razões do coração. A experiência da conversão foi adequada para resolver o problema existencial. Logo, ela deve ser verdadeira. Qualquer insinuação da dúvida, assim, contém sempre em si a ameaça de que a consciência reverta ao seu estado primitivo de angústia. ${ }^{6}$

Desta forma, se criam mecanismos que impedem a reestruturação da fé a partir da racionalidade teológica, pois isto traz o perigo do retorno às experiências de angústia. ${ }^{69} \mathrm{O}$ medo do estudo teológico estaria relacionado ao perigo da perda desta experiência fundante, esta que lhe livrou de temores e culpas. Portanto, impõe mecanismos de defesa contra sua reestruturação racional. Desta forma, parece que o pentecostal quer viver sempre a sua experiência fundante, comportando-se como um neoconverso para que o sagrado não se esvaeça ou perca sua força. Não há como negar que este não procure a inteligibilidade de sua fé, mas somente até o ponto onde esta não comprometa a experiência fundante e as experiências posteriores.

Segundo Alves, toda racionalidade, religiosa ou científica, se fundamenta em "experiências pré-racionais emotivas". Nisso corrobora Durkheim quando salienta que as "categorias fundamentais do pensamento e, consequentemente, da ciência são de origem religiosa".$^{70}$ Assim "a racionalidade religiosa não é uma expressão de uma experiência fundamental, mas antes um mascaramento desta". ${ }^{71}$ Nesta mesma linha segue-se o que Schleiermacher afirmou: a "letra" (racionalidade) é subordinada ao "espírito", e a matriz fundamental da vida espiritual é o "coração" (espírito). ${ }^{72}$

\section{Considerações finais}

O caminho traçado neste artigo foi elaborar a transversalidade do sagrado de Rudolf Otto presente, assim como em outras expressões religiosas, no pentecostalismo e perceber as várias categorias elaboradas pelo autor verificáveis no pentecostalismo, certamente por este último apelar mais às categorias não racionais e portanto emotivas e experienciais, pode encontrar mais sentido com a obra de Otto.

\footnotetext{
ALVES, 2005, p. 98.

ALVES, 2005, p. 99-100.

DURKHEIM, 2000, p. 103.

ALVES, 2005, p. 103.

72 DREHER, Luís Henrique. O método teológico de Friedrich Schleiermacher. 2.ed. São Leopoldo: Sinodal/IEPG, 2003. p. 53-54.
} 
Se verificou que o pentecostalismo expressa em boa medida uma ampla categoria de manifestações do numinoso, especialmente por meio das ditas manifestações do Espírito Santo, em que o crente é enlevado em suas emoções mais profundas ao contato com o divino na sua experiência de fé, atestando assim para a realidade última da vida que a tudo completa e preenche naqueles que se dispõe a serem atingidos por ela.

\section{Referências}

ALVES, Rubem. Religião e repressão. São Paulo: Teológica/Loyola, 2005.

BARTZ, Alessandro. Percursos religiosos e adesão: comunidades urbanas da IECLB como estudo de caso. 2013. Tese (Doutorado) - Programa de Pós-Graduação em Teologia, Escola Superior de Teologia, São Leopoldo, 2013.

BASTIDE, Roger. Estudos afro-brasileiros. São Paulo: Perspectiva, 1972.

BERGER, Peter L. O dossel sagrado: elementos para uma teoria sociológica da religião. São Paulo: Paulinas, 1985.

BIRCK, Bruno Odélio. O sagrado e Rudolf Otto. Porto Alegre: EDIPUCRS, 1993.

BOMFIM, Adailson Jose Rosendo. Um “alarido" neopentecostal: diversidade e ressignificação simbólica na Igreja Universal do Reino de Deus. Scientia Plena, São Cristovão, v. 3, n. 5, p. 66, 2007.

CROATTO, José Severino. As linguagens da experiência religiosa: uma introdução à fenomenologia da religião. São Paulo: Paulinas, 2001.

D'EPINAY, Christian Lalive. El refugio de las masas: estudio sociológico del protestantismo chileno. Concepción (Chile): USACH/IDEA/CEEP, 2010.

DREHER, Luís Henrique. O método teológico de Friedrich Schleiermacher. 2.ed. São Leopoldo: Sinodal/IEPG, 2003.

DURKHEIM, Émile. As formas elementares da vida religiosa: o sistema totêmico na Austrália. São Paulo: Martins Fontes, 2000.

ELIADE, Mircea. Aspectos do mito. Lisboa: Edições 70, 1963.

. O sagrado e o profano: a essência das religiões. 2.ed. São Paulo: Martins Fontes, 2008.

HOLLENWEGER, Walter J. El Pentecostalismo: Historia y doctrinas. Buenos Aires: La Aurora, 1976.

LEENHARDT, Maurice. O mito. Religião e sociedade, Rio de Janeiro, v. 14, n. 1, p. 90, mar. 1987.

LOBOS, Daniel. Problemas y desafíos que presenta el educando pentecostal al plan de estudios teológico de nivel universitario. In: CHIQUETE, Daniel; ORELLANA, Luis. 
(Eds.). Voces del pentecostalismo Latinoamericano: identidade, teologia e historia. v. 8. Concepción (Chile): RELEP/CETELA/ASETT, 2003.

MENDONÇA, Antônio Gouvêa; VELASQUES FILHO, Prócoro. Introdução ao protestantismo no Brasil. São Paulo: Loyola, 1990.

OTTO, Rudolf. O sagrado. São Leopoldo: Sinodal/EST; Petrópolis: Vozes, 2007.

POMMERENING, Claiton Ivan. Oralidade e escrita na Teologia Pentecostal. Azusa Revista de Estudos Pentecostais, Joinville, v. I, n. 1, p. 23-62, jul. 2010.

QUEIROZ, Maria Isaura Pereira de. Rumos do pensamento etnológico na França: a atualidade de Maurice Leenhardt. Religião e Sociedade, Rio de Janeiro, v. 14, n. 1, p. 72, mar. 1987.

REBLIN, Iuri A. Outros cheiros, outros sabores... o pensamento teológico de Rubem Alves. São Leopoldo: Oikos, 2009.

RICOEUR, Paul. Interpretação e ideologias. 2.ed. Rio de Janeiro: F. Alves, 1988.

RIVERA, Paulo Barrera. Tradição, transmissão e emoção religiosa: sociologia do protestantismo na América Latina. São Paulo: Olho d'Água, 2001.

SOUZA, Alexandro Ferreira de. A narrativa de um malogro: vivência e linguagem religiosas em A paixão segundo G.H., de Clarice Lispector, examinadas a partir de Rudolf Otto. 2009. Dissertação (Mestrado em Teologia) - Programa de Pós-Graduação em Ciência da Religião, Universidade Federal de Juiz de Fora, Juiz de Fora, 2009.

SUNG, Jung Mo; MIGUEZ, Nestor; WIRTH, Lauri. Missão e educação teológica. São Paulo: Aste, 2011.

TRÍAS, Eugenio. Pensar a religião: o símbolo e o sagrado. In: DERRIDA, Jacques; VATTIMO, Gianni (Orgs.). A religião. São Paulo: Estação Liberdade, 2000.

WACH, Joaquim. Sociologia da religião. São Paulo: Paulinas, 1990.

WEBER, Max. Economia e sociedade: fundamentos da sociologia compreensiva. Brasília: UNB; São Paulo: IOESP, 1999. 